TAHKIM, Jurnal Peradaban dan Hukum Islam. Vol.2 No.2 (0ktober, 2019) | ISSN : 2597-7962

\title{
POTENSI MASJID AGUNG TRANS STUDIO BANDUNG DALAM PEMBERDAYAAN EKONOMI MASYARAKAT BERBASIS MASJID DENGAN ANALISIS SWOT
}

Muhammad Fauzi Arif

Fakultas Dakwah Universitas Islam Bandung muhammadfauziarif@gmail.com

\begin{abstract}
ABSTRAK
Tujuan pemberdayaan ekonomi berbasis masjid yaitu meningkatkan kemandirian dan kesejahteraan umat. Masjid diharapkan mampu memenuhi kebutuhan finansial serta berperan dalam menciptakan masyarakat yang sejahtera secara mandiri. Pemberdayaan ekonomi masyarakat lokal tidak terbatas pada usaha-usaha memproduksi barang dan jasa saja tetapi juga mencakup pelatihan dan pendampingan, pembiayaan atau akses permodalan dan akses pemasaran. Penelitian ini mengkaji potensi Masjid Agung Trans Studio Bandung dan memberi gambaran tentang peluang dan tantangan yang dihadapi dalam pemberdayaan ekonomi masyarakat sekitarnya.
\end{abstract}

Kata kunci: masjid, pemberdayaan, ekonomi.

\begin{abstract}
Masjid-based economic empowerment aims to improve the independence and welfare of the people. Masjid is expected to be able to meet financial needs and play a role in creating a prosperous society independently. Economic empowerment of local communities is not limited to businesses producing and services but also includes training and mentoring, financing or access to capital and access to marketing. This study examines the potential of Masjid Trans Studio Bandung and provides an overview of opportunities and challenges in empowering the economy of the surrounding community.
\end{abstract}

Keywords: masjid, empowerment, economy. 
TAHKIM, Jurnal Peradaban dan Hukum Islam. Vol.2 No.2 (0ktober, 2019) | ISSN : 2597-7962

\section{A. PENDAHULUAN}

Masjid memiliki fungsi beragam selain sebagai tempat peribadatan, seperti tempat pendidikan, pembinaan umat dan fungsi sosial lainnya. Pada zaman milenial ini, masjid harus ditransformasikan menjadi tempat yang paling aktif untuk menghasilkan karya, gerakan perubahan dan poros peradaban, salah satunya pemberdayaan ekonomi masyarakat

Pemberdayaan ekonomi masyarakat berbasis masjid merupakan usaha meningkatan kemampuan dan sumber daya yang dimiliki masjid dan masyarakat, bertujuan untuk kemandirian, memenuhi kebutuhan hidup serta meningkatkan kesejahteraan umat. Said Tuhuleley mendeskripsikan masjid memiliki misi, yaitu sebagai wahana pembersihan diri, pembebasan dan pemberdayaan. Masjid bertugas mewujudkan manusia yang tidak diperbudak oleh sesamanya dan oleh makhluk-makhluk lainnya ${ }^{1}$.

Catatan sejarah menunjukkan kegiatan pemberdayaan ekonomi umat berbasis masjid telah dilaksanakan pada masa Rasulullah SAW dan diteruskan oleh para khalifah hingga dinasti-dinasti Islam setelahnya. Misalnya di Masjid Nabawi, selain melaksanakan aktivitas menimba ilmu, berdiskusi persoalan politik, Rasul juga melakukan aktivitas pengembangan ekonomi masyarakat ${ }^{2}$.

Masjid-masjid di Indonesia masih disakralkan pada aspek ibadah mahdlah semata, fungsi masjid sebagai penggerak kegiatan sosial dan ekonomi umat kurang mendapat perhatian dari para pengelola masjid, maka tersebarlah masjid-masjid yang megah, tapi sepi dari aktivitas umat. Padahal masjid sebagai tempat berkumpul umat merupakan wadah yang efektif untuk melaksanakan kegiatan-kegiatan dakwah, pendidikan, sosial, bahkan ekonomi. Sebut saja Masjid Jogokariyan di Yogyakarta, salah satu masjid yang telah melakukan penataan manajemen dengan baik. Pada dokumen resmi masjid, visi dari Masjid Jogokariyan Yogyakarta adalah "Terwujudnya masyarakat sejahtera lahir bathin yang

${ }^{1}$ Said Tuhuleley, Masjid, Rekonstruksi Wawasan Kemanusiaan, dan Pembangunan Umat. Seminar Nasional Milad Masjid Syuhada: Yogyakarta, 2002.

2 Lihat Johan H. Meuleman (ed.) Islam in the Era Globalization: Muslim Attitudes Towards Modernity and Identity. London: Routledge, 2002. dan Mohammad Tajuddin Haji Mohammad Rasdi, The Mosque as a Community Development Centre: Programme and Architectural Guidelines for Contemporary Muslim Societies. (Johor Bahru: UTM, 1998). 
diridhoi Allah melalui kegiatan kemasyarakatan yang berpusat di Masjid"3 visi tersebut menggambarkan bahwa masjid merupakan pusat kegiatan dalam memakmurkan masyarakat sekitarnya jika dikelola dengan baik.

Lembaga takmir masjid di manapun sebenarnya memiliki peluang untuk ikut aktif memberdayakan ekonomi masyarakat, namun sayangnya belum diupayakan secara maksimal. Masjid sebenarnya memiliki modal unik yang tidak dimiliki oleh lembagalembaga lain pada umumnya. Penelitian tentang potensi masjid dalam melaksanakan program pemberdayaan masyarakat dalam hal keuangan mikro (micro finance) menunjukkan 90 persen responden yakin masjid mampu melaksanakan program mikro kredit. Hal ini berdasarkan penelitian di Kelantan Malaysia, dimana para responden terdiri dari para pakar dan praktisi keuangan mikro. Penelitian tersebut menyimpulkan bahwa para pengurus takmir masjid mengenal masyarakat sekitarnya dengan sangat baik, sebuah kawasan atau mukim yang berada di bawah administasi sebuah masjid tidak terlalu luas dan anggota kepanitiaan pengurus masjid biasanya terdiri dari para pemuka masyarakat sekitarnya, karena itu mereka sangat mengenal masyarakatnya atau orang-orang yang menjadi sasaran dari program tersebut adalah benar-benar orang yang sangat membutuhkan. ${ }^{4}$

Kegiatan pemberdayaan ekonomi masyarakat di Bandung saat ini masih dilakukan oleh beberapa lembaga seperti lembaga-lembaga zakat. Kegiatan-kegiatan pemberdayaan ekonomi yang potensial ditujukan kepada masyarakat miskin, kelompok usaha kecil dan kelompok swadaya masyarakat meliputi pelatihan kewirausahaan, pembiayaan (akses permodalan) serta akses pemasaran. Namun sayangnya kegiatan-kegiatan tersebut tidak lagi memiliki hubungan khas yang bersimbiosis dengan masjid, padahal lembaga masjid berada di tengah-tengah masyarakat dan masjid lebih mengetahui persoalan-persoalan masyarakat di sekitarnya.

${ }^{3}$ Erdin Sumardiant, Manajemen strategis Masjid Jogokariyan Yogyakarta. PhD thesis, (Surabaya: Universitas Islam Negeri Sunan Ampel Surabaya, 2017), hlm. 112.

${ }^{4}$ Kamaruddin, Analisis Potensi Pemberdayaan Ekonomi Masyarakat Berbasis Masjid Di Kota Banda Aceh. Jurnal Ilmiah ISLAM FUTURA, Vol 13 No 1, Agustus 2013, hlm. 60. 
Berdasarkan data Sistem Informasi Masjid (SIMAS) Kementerian Agama Republik Indonesia, bahwa jumlah masjid di Kota Bandung sebanyak 2.246, 78 masjid di antaranya masuk dalam kategori masjid di tempat publik, ${ }^{5}$ salah satunya adalah Masjid Agung Trans Studio.

Masjid Trans Studio Bandung (MTSB) merupakan masjid yang berbeda dengan masjid lainnya di Kota Bandung, karena letaknya berada di kawasan bisnis Trans Studio Mall dan wahana bermain Trans Studio Bandung, suatu kawasan yang biasanya dikunjungi oleh masyarakat menengah ke atas. Standar pelayanan serta fasilitas yang dimiliki oleh masjid ini terbilang baik, terlihat dari arsitektur bangunannya mirip dengan masjid nabawi, memiliki ruang VVIP untuk tamu atau ruang tunggu bagi para khotib/penceramah, dan kebersihannya yang terjaga. Masjid ini tidak pernah sepi dari kegiatan kajian Islam setiap harinya, mayoritas kajian diselenggarakan oleh Majlis Ta'lim, Ormas Islam maupun komunitas-komunitas kajian Islam, seperti Pemuda Hijrah, MIM Foundation, One Ummah dan lain-lain. Bangunan infrastruktur masjid yang eksotis, megah disertai sarana prasarana masjid yang memadai dengan infak jamaah kurang lebih Rp. 100.000.000 per bulan. Untuk mewadahi, mengelola, dan mengoptimalkan infak jamaah itu, maka pihak DKM membentuk unit pengelolaam dana zakat, infaq dan shodaqoh. ${ }^{6}$ Berdasarkan hal itu maka masjid ini layak sebagai tempat penelitian berkaitan dengan potensi pemberdayaan ekonomi masyarakat berbasis masjid di Kota Bandung.

Penelitian ini akan menganalisis potensi pemberdayaan ekonomi masyarakat berbasis masjid di Masjid Trans Studio Bandung, kemudian fokus kajian tentang potensi tersebut akan diuraikan berkaitan dengan kekuatan (strength), kelemahan (weakness), peluang (opportunity), dan tantangan (threat).

\footnotetext{
${ }^{5}$ Lihat: http://simas.kemenag.go.id.

${ }^{6}$ Wawancara ketua DKM Masjid Trans Studio Bandung.
} 


\section{B. PEMBAHASAN}

\section{Konsep Pengembangan Masjid}

Adanya pelaksanaan kegiatan-kegiatan yang bermanfaat bagi umat merupakan salah satu indikator kemakmuran suatu masjid. Kegiatan sosial ekonomi masyarakat merupakan salah satu elemen penting untuk direncanakan ketika tokoh-tokoh masyarakat berkumpul di masjid. Lembaga masjid perlu mencari solusi bagaimana menyelesaikan persoalan dan kesulitan yang dihadapi oleh jamaah sehingga ukhuwah islamiyyah di antara jamaah masjid tetap terbina. Di antara persoalan yang seringkali menimpa jamaah atau masyarakat sekitar pada umumnya adalah persoalan ekonomi dimana keluarga-keluarga miskin tidak mampu mencukupi kebutuhan primer. Disamping itu banyak diantara para pelaku usaha kecil menghadapi kesulitan modal dan minimnya pengetahuan tentang kewirausahaan. Mereka ingin sekali dibantu dan dicarikan solusi agar segera keluar dari persoalan-persoalan tersebut.

Masjid mempunyai potensi untuk membantu memecahkan persoalan tersebut dengan program pemberdayaan ekonomi berbasis masjid. Yang dimaksud dengan ekonomi masyarakat berbasis masjid adalah kegiatan perekonomian yang dilakukan oleh masyarakat dimana pelaksanaan dan pengembangannya didukung oleh takmir masjid. Menurut Ginanjar Kartasasmita, pemberdayaan ekonomi masyarakat merupakan salah satu upaya yang harus dilakukan untuk membangun ekonomi nasional yang tangguh dan mandiri. Meningkatkan kemampuan masyarakat merupakan akar persoalan dari kegiatan pemberdayaan, yaitu "upaya pengerahan sumber daya untuk mengembangkan potensi ekonomi rakyat, ini diarahkan untuk meningkatkan produktivitas rakyat sehingga sumber daya manusia maupun sumber daya alam di sekitar rakyat, dapat ditingkatkan produktivitasnya." 7

Kegiatan pemberdayaan ekonomi masyarakat tidak terbatas pada usaha-usaha memproduksi barang dan jasa saja tetapi juga mencakup pelatihan dan pendampingan,

${ }^{7}$ Ginandjar Kartasasmita. Pemberdayaan Ekonomi Rakyat Melalui Kemitraan Guna Mewujudkan Ekonomi Nasional Yang Tangguh Dan Mandiri. disampaikan pada seminar nasional Lembaga pembinaan pengusaha kecil menengah dan koperasi (LP2KMK-GOLKAR) Jakarta, 7 Nopember 1996. 
pembiayaan atau akses permodalan dan akses pemasaran. Segmen kewirausahaan yang menjadi perhatian dalam ekonomi berbasis masjid adalah usaha kecil yang dimiliki dan dikelola oleh masyarakat di sekitar masjid. Usaha kecil di Indonesia adalah potret ekonomi rakyat pada umumnya ditekuni oleh masyarakat miskin, namun bukan berarti mereka tidak memiliki modal melainkan mereka memilikinya secara terbatas padahal mereka merupakan masyarakat yang aktif secara ekonomi dan mereka lebih memerlukan aksesibilitas pada service provider (dalam hal ini lembaga keuangan) dari pada belas kasihan. ${ }^{8}$ Karena itu mereka perlu dibantu untuk mendapatkan akses pada lembaga keuangan.

Pembiayaan modal usaha bagi usaha kecil bertujuan supaya dapat berkembang dan mandiri. Akses pada permodalan merupakan salah satu pra syarat bagi usaha kecil untuk tumbuh dan menjadi penopang ekonomi masyarakat terutama di pedesaan. Banyak negara berkembang yang menekankan pentingnya peranan keuangan mikro dalam pengentasan kemiskinan di kalangan kaum miskin. ${ }^{9}$ Pada umumnya, jenis pembiayaan yang diberikan kepada kelompok usaha kecil berupa pinjaman kredit mikro, dana bergulir dan kredit tanpa agunan. Keuangan mikro atau micro finance adalah kegiatan memberikan pinjaman yang jumlahnya kecil kepada masyarakat miskin untuk kegiatan usaha meningkatkan pendapatan, pemberian pinjaman untuk mengurus diri sendiri dan keluarganya. ${ }^{10}$

Pemberian pinjaman mikro kepada orang miskin telah dianggap sebagai upaya penting dalam memerangi kemiskinan, mengingat selama ini mereka mendapatkan banyak hambatan ketika hendak mengakses pinjaman dari lembaga perbankan konvensional. Studi tentang dampak pinjaman mikro bagi perempuan penerima di Indonesia, menunjukkan rumah tangga yang memperoleh pinjaman keuangan mikro, relatif lebih baik dalam hal kesejahteraan dibanding rumah tangga yang tidak mendapat pinjaman keuangan mikro. ${ }^{11}$

\footnotetext{
${ }^{8}$ Bambang Ismawan, Pemberdayaan Masyarakat melalui Dana Bergulir. disampaikan pada diskusi “Visi Bersama Ekonomi Kerakyatan” Ekonomi Kerakyatan sebagai Gerakan Pembangunan, 22 Januari 2009, Depok, Jawa Barat.

${ }^{9}$ Caroline Moser, Third World Policy Ap-proaches to Women in Development (London: Routledge, 1992).

${ }^{10}$ Pengertian yang diberikan oleh The world Summit on Microcredit di Washington pada tanggal 2-4 Februari 1997.

${ }^{11}$ Sulikah Asmorowati, Dampak Pemberian Kredit Mikro untuk Perempuan: Analisis Pengadopsian Model Grameen (Surabaya:Universitas Airlangga, t.th).
} 
Beberapa masjid di tanah air telah mendirikan lembaga Baitul Mal Wa Tamwil atau disingkat BMT, yaitu "sebagai wadah untuk mengumpulkan harta yang bersumber dari potensi masyarakat, yang kemudian dimanfaatkan dan dikelola sesuai dengan tuntunan syariah, dari, oleh dan untuk masyarakat sendiri dalam rangka meningkatkan taraf kesejahteraan dan memperkuat ekonomi umat"12

BMT menghimpun modal yang bersumber dari masyarakat dan menyalurkannya pada usaha-usaha produktif dalam rangka menciptakan nilai tambah baru dan mendorong pertumbuhan ekonomi masyarakat dan membawa manfaat secara keuangan baik kepada pemilik dan juga kepada peminjam. Modal yang dikumpulkan tersebut berasal dari wakaf, infaq, sadaqah dan keuntungan yang diperoleh dari kegiatan usaha produktif (generated income). Adapun pendapatan (generated income) yang diperoleh oleh BMT masjid dapat didistribusikan untuk berbagai tujuan bagi umat dengan tujuan sebagai berikut $:^{13}$

a. Sumbangan (charity) yang ditujukan untuk bagi orang-orang yang tidak mampu memenuhi kebutuhan-kebutuhan hidup.

b. Pemberdayaan (empowerment) yang ditujukan bagi orang-orang atau sekelompok orang yang mempunyai usaha yang prospektif tetapi memiliki keterbatasan dalam permodalan dan akses untuk mendapatkan tambahan modal untuk mengembangkan usaha. Dilakukan sesuai dengan prinsip syariah seperti mudharabah, musharakah, dan murabahah.

c. Investasi Sumber Daya Manusia (human investment), penyediaan fasilitas pendidikan melalui beasiswa dan pelatihan untuk memperbaiki kualitas SDM.

d. Investasi Infrastruktur (infrastructure investment), penyediaan fasilitas fisik seperti sekolah, fasilitas kesehatan dan sebagainya yang bertujuan memperbaiki kesejahteraan masyarakat sekitar.

12 M. Hajar Dewantoro, 2005, Pengembangan BMT Berbasis Masjid Studi Kasus BMT AlAzka Pagerharjo (Samigaluh Kulonprogoal-Mawarid Edisi Xiii, 2005)

13 Achmad Tohirin, The Cash Waqf For Empowering The Small Businesses. Center For Islamic Economics Development And Studies (P3EI).Yogyakarta: Faculty of Economics, Universitas Islam Indonesia. disampaikan padaSeventh International Conference - The Tawhidi Epistemology: Zakat And Waqf Economy, Bangi 2010. 


\section{Potensi Pemberdayaan Ekonomi Masyarakat Berbasis Masjid}

Pengalaman di berbagai Negara ke tiga menunjukkan program-program mikro kredit yang ditujukan untuk pemberdayaan masyarakat telah banyak membantu usaha pemerintah untuk mengurangi angka kemiskinan dan tingkat penganguran. Para pemikir pemberdayaan masyarakat (community empowerment) dan keuangan mikro (micro finance) telah memberikan masukan-masukan terkait dengan pelaksanaan kedua hal tersebut di lembaga masjid. Mereka berkeyakinan lembaga masjid punya potensi untuk ikut ambil bagian dalam pemberdayaan ekonomi masyarakat terutama masyarakat di sekitar masjid.

Kelembagaan yang sudah eksis di sejumlah masjid membuka peluang bagi pembentukan lembaga-lembaga khusus seperti BMT atau Baitul Qiradh. Di samping itu lembaga-lembaga masjid yang sudah ada perlu peningkatan kapasitas SDM yang siap untuk merancang program, mengimplementasi, memonitor dan mengkoordinasikan dengan para stakeholder.

Hasil peninjauan ke Masjid Agung Trans Studio Bandung apabila dilihat dari hasil kencleng jama'ah setiap minggunya kurang lebih menembus 20 juta rupiah dan anggaran pengeluaran dana sosial sekitar tiga puluh hingga 40 juta rupiah setiap bulannya. Dan secara struktur organisasi Masjid Agung Trans Studio Bandung sudah memiliki lembaga pengelolaan ZIS. Maka Masjid Agung Trans Studio Bandung dinilai cukup siap untuk melakukan pemberdayaan masyarakat secara inten . Jika kegiatan pemberdayaan ekonomi masyarakat berbasis masjid digarap dengan serius maka akan membantu pemerintah dalam memerangi kemiskinan dan persoalan pengangguran minimal di lingkungan masyarakat sekitar Masjid Agung Trans Studio Bandung.

Oleh karena itu secara gambaran umum Masjid Agung Trans Studio Bandung memiliki kapasitas untuk melaksanakan kegiatan pemberdayaan yang bertujuan untuk membangun masyarakat yang mandiri dan sejahtera dengan mengoptimalkan potensi yang ada pada masjid dan lingkungan sekitarnya. Kapasitas tersebut berupa finansial dan 
kelembagaan yang telah ada dan dapat dioptimalkan fungsi dan perannya pada tahap awal, dengan mengadopsi beberapa hal sebagai berikut: ${ }^{14}$

a. Pembentukan BMT (Baitul Mal Wattamwil). Masjid dengan aktifitas kegiatan ekonomi yang dimotori oleh BMT yang didirikannya akan sanggup menjadi basis pemberdayaan ekonomi para jamaahnya, maupun umat Islam di sekitarnya secara luas.

b. Rekruitmen SDM untuk pelatihan dan pengembangan skill kewirausahaan;

c. Membangun kemitraan dengan lembaga pengembangan ekonomi masyarakat, seperti Kelompok Swadaya Masyarakat, Lembaga Keuangan Syariah dan lain sebagainya.

\section{Analisis SWOT Pemberdayaan Ekonomi Masyarakat Berbasis Masjid}

Penelitian ini akan menjelaskan potensi pemberdayaan ekonomi masyrakat berbasis masjid yang dimiliki oleh Masjid Trans Studio Bandung menggunakan analisis SWOT, yaitu; dengan kekuatan (strength), kelemahan (weakness), peluang (opportunity), dan tantangan (threat).

Kekuatan (Strength) yaitu situasi atau kondisi yang merupakan kekuatan dari masjid dan program yang sedang dijalankan saat ini. Kekuatan merupakan faktor internal yang melekat pada masjid atau lembaga masjid:

a. Masjid Agung Trans Studio Bandung memiliki organisasi kepengurusan masjid di mana para anggotanya terdiri dari para karyawan Trans Studio Mall yang pada umumnya punya kapasitas manajemen.

b. memiliki income (dana umat) yang banyak.

c. Memiliki lembaga pengelola ZIS.

d. Adanya anggaran khusus untuk kegiatan sosial setiap bulannya

e. Masjid punya hubungan yang dekat dengan masyarakat dan mengenal masyarakat sekitarnya lebih dalam;

\footnotetext{
14 Arif Hamzah, Peran Masjid Dalam MeningkatkanPerekonomian Masyarakat (http:www.foxitsoftware.com)
} 
f. Sistem administrasi dan pelaporan berjalan dengan baik;

Kelemahan (weakneses) yaitu situasi atau kondisi yang merupakan kelemahan dari masjid atau program pada saat ini. Kelemahan merupakan faktor internal yang melekat pada masjid atau lembaga masjid:

a. Masjid belum mengenal pelaku usaha-usaha kecil yang sudah eksis dan peluang usaha yang ada di lingkungan sekitarnya;

b. Masjid belum memiliki SDM yang memadai untuk melaksanakam program pemberdayaan ekonomi masyarakat;

c. Pengelola ZIS masjid masih kurang memahami sepenuhnya ekonomi syari'ah.

d. Pada umumnya dana yang terkumpul belum dimanfaatkan untuk kegiatan ekonomi (produktif). Dana infak dari jamaah selama ini hanya dikeluarkan untuk biaya operasional, bantuan anak yatim dan dlu'afa, bantuan pembangunan masjid-masjid lain, bantuan dana pendidikan, bantuan bencana alam, dll.

Peluang (Opportunity) yaitu situasi atau kondisi yang merupakan peluang dari masjid atau program pada saat ini. Peluang merupakan faktor eksternal yang berasal dari lingkungan sekitar masjid berada:

a. Pelaku usaha kecil membutuhkan pembiayaan mikro karena mereka tidak dapat mengakses pinjaman dari Bank;

b. Bisnis pemula membutuhkan modal kerja untuk pengembangan usaha;

c. Usaha kecil di lingkungan sekitar membutuhkan skill manajemen keuangan dan akses pada pemasaran.

Tantangan (threat) yaitu situasi atau kondisi yang merupakan tantangan dari masjid atau program pada saat ini. Tantangan merupakan faktor ekternal yang berasal dari lingkungan sekitar masjid berada. Beberapa tantangan tersebut adalah sebagai berikut:

a. Belum tentu masyarakat sekitar merespon positif terhadap program yang dirancang oleh masjid.

b. Mental masyarakat yang lemah dalam upaya meningkatkan kemandirian.

c. Munculnya aksi penipuan-penipuan yang terorganisir berkedok program bagi hasil. 
TAHKIM, Jurnal Peradaban dan Hukum Islam. Vol.2 No.2 (0ktober, 2019) | ISSN : 2597-7962

d. Pandangan keliru sebagian masyarakat tentang "pinjaman modal usaha tidak perlu dikembalikan";

e. Keengganan para peminjam modal untuk mengikuti pelatihan kewirausahaan

\section{SIMPULAN}

Potensi Masjid Agung Trans Studio Bandung dalam pemberdayaan ekonomi masyarakat berbasis masjid, di antaranya: (1) Potensi sumber pendanaan, (2) Potensi lembaga dan jaringan, (3) Potensi iklim usaha/bisnis di lingkungan sekitar; dan (4) Dukungan yang ditunjukkan oleh stakeholder.

Adapun saran dari peneliti, di antaranya bahwa pemberdayaan ekonomi berbasis masjid ini, perlu melibatkan semua pihak termasuk pemerintah Kota Bandung. Kegiatan pemberdayaan ini hendaknya memiliki koneksitas dengan program-program pemerintah baik pemerintah kota, provinsi dan pusat. Dengan demikian program ini akan mendapatkan dukungan yang optimal.

Selain itu, pengurus masjid perlu membangun kemitraan terutama dengan lembaga pengembangan ekonomi masyarakat, seperti Kelompok Swadaya Masyarakat (KSM), Lembaga Keuangan Perbankan Syariah, Lembaga Zakat dan konsultan UMKM yang dibina oleh Bank Indonesia. Hal ini dikarenakan kemitraan akan membantu masjid dalam gagasan perencanaan dan implementasi program-program pemberdayaan. Sebagai tambahan, peningkatan SDM dengan pelatihan dan pengembangan skill managemen, akuntansi bisnis, dan kewirausahaan juga akan sangat membantu proses pemberdayaan. 
TAHKIM, Jurnal Peradaban dan Hukum Islam. Vol.2 No.2 (0ktober, 2019) | ISSN : 2597-7962

\section{DAFTAR PUSTAKA}

Asmorowati, Sulikah, (2005) .Dampak Pemberian Kredit Mikro untuk Perempuan: Analisis Pengadopsian Model Grameen. Surabaya: Universitas Airlangga,

Dewantoro, M. Hajar. (2005). Pengembangan BMT Berbasis Masjid Studi Kasus BMT AlAzka Pagerharjo Samigaluh Kulonprogo Jurnal al-Mawarid Edisi XIII.

Hamzah, Arif. (2011) Peran Masjid Dalam Meningkatkan Perekonomian Masyarakat.

Ismawan, Bambang, (2009). Pemberdayaan Masyarakat melalui Dana Bergulir disampaikan pada diskusi "Visi Bersama Ekonomi Kerakyatan" Ekonomi Kerakyatan sebagai Gerakan Pembangunan, Depok.

Kartasasmita, Ginandjar. (1996 ) Pemberdayaan Ekonomi Rakyat Melalui Kemitraan Guna Mewujudkan Ekonomi Nasional Yang Tangguh Dan Mandiri. Makalah, disampaikan pada seminar nasional Lembaga pembinaan pengusaha kecil menengah dan koperasi (LP2KMK-GOLKAR) Jakarta.

Meuleman, Johan H. (ed. ). Islam in the Era Globalization: Muslim Attitudes Towards Modernity and Identity. London: Routledge.

Moser, Caroline. (1992) Third World Policy Ap-proaches to Women in Development. London: Routledge,

Tohirin, Achmad. (2010.) The Cash Waqf For Empowering The Small Businesses. Yogyakarta: Center for Islamic Economics Development and Studies (P3EI) Faculty of Economics, Universitas Islam Indonesia,

Tuhuleley, Said. (2002.) Masjid, Rekonstruksi Wawasan Kemanusiaan, dan Pembangunan Ummat, Seminar Nasional Milad Masjid Syuhada. Yogyakarta.

Yusoff, Asry Abdullah Sudin Ab. Rahman, Mohd. Noor Shapiinh. (t.th.) A Study on the Possibility of Mosque Institution Running a Micro-Credit Programme Based on the Grameen Bank Group Lending Model: The Case of Mosque Institution in Kelantan, Malaysia: t.p, 